\title{
How Do I Learn You? Towards Designing an Approach in Unlearning Negative Habits
}

\author{
Jose Miguel Cruz Jazmines ${ }^{1}$, Inero Valbuena Ancho,** \\ ${ }^{1}$ Elizabeth Seton School, Philippines, ${ }^{2}$ Philippine Normal University, Philippines \\ *corresponding e-mail: ancho.iv@pnu.edu.ph
}

Received: 13 September 2019 Accepted: 14 Oktober 2019 Online Published: 07 November 2019

\begin{abstract}
How Do I Unlearn You? Towards Designing an Approach in Unlearning Negative Habits. Objectives: The study intends to explore and understand the unlearning process, as grounded from the experiences of teachers and students of Edukasyon sa Pagpapakatao (Values Education in the Philippines) towards developing a new approach in teaching the aforementioned subject area. Methods: Interviews were conducted to 33 respondents from a private Catholic school, and transcripts were analyzed through the techniques of thematic analysis and grounded theory. Findings: The adolescents' negative habits, as well as teachers' facilitation practices generated substantial themes such as: (1) need for a strong sense of self; (2) difficulty of unlearning due to various "blocks"; (3) instruments to unlearn; and (4) role of teachers as empathic individuals. These codes then led to the final product of the study as E.L.S.A.'s approach to unlearn (Empowering the Self, Letting Go, Starting a New Life, and Action), which may be utilized as schools' pedagogical framework in producing classroom-based materials in facilitating values formation. Conclusion: The idea of unlearning is not an experimental process or behavioral modification. It only explored the concept and process of unlearning, but did not necessarily aim to make unlearning take place on the psyche of the students.
\end{abstract}

Keywords: Unlearning negative habits, edukasyon sa pagpapakatao (values education), teaching approaches, adolescence, thematic analysis.

Abstrak: Bagaimana Saya Belajar Meninggalkannya? Merancang Suatu Pendekatan dalam Menghilangkan Kebiasaan Negatif. Tujuan: Penelitian ini bertujuan untuk mengeksplorasi dan memahami proses pembelajaran, yang didasarkan pada pengalaman para guru dan siswa Edukasyon sa Pagpapakatao (Pendidikan Nilai di Filipina) untuk mengembangkan pendekatan baru dalam mengajar bidang studi tersebut. Metode: Wawancara dilakukan kepada 33 responden dari Elizabeth Seton School, dan transkrip dianalisis melalui teknik analisis tematik dan grounded theory. Temuan: Kebiasaan negatif remaja, maupun tindakantindakan guru menghasilkan tema-tema substansial seperti: (1) kebutuhan akan perasaan diri yang kuat; (2) kesulitan untuk belajar karena berbagai "blok"; (3) instrumen untuk melepaskan; dan (4) peran guru sebagai individu yang empatik. Kode-kode ini kemudian mengarah ke produk akhir dari penelitian yaitu dihasilkannya pendekatan E.L.S.A (Empowering the Self, Letting Go, Starting a New Life, and Action), yang memungkinkan untuk digunakan sebagai kerangka pedagogis sekolah dalam memproduksi materi berbasis ruang kelas dalam memfasilitasi pembentukan nilai-nilai. Kesimpulan: Gagasan unlearning bukanlah proses eksperimental atau modifikasi perilaku. Itu hanya mengeksplorasi konsep dan proses unlearning, tetapi tidak selalu bertujuan untuk membuat unlearning terjadi pada jiwa siswa.

Kata kunci: Menghilangkan kebiasaaan negatif, pendidikan nilai, pendekatan pengajaran, remaja, analisis tematik.

\section{To cite this article:}

Jazmines, J. M. C. \& Ancho, I. V. (2019). How Do I Unlearn You? Towards Designing an Approach in Unlearning Negative Habits. Jurnal Pendidikan Progresif, 9(2), pp. 132-145. doi: 10.23960/jpp.v9.i2.201916 


\section{INTRODUCTION}

\section{Background of the Study}

In the process of learning new information, individuals go through a phase of releasing or reframing of knowledge. As a matter of fact, it is opined that "the goods at the back of our mental warehouse not only gather dust and deteriorate, but also actively infect new stocks with old ways and old concepts"(Wilson, 1988). Furthermore, as defined by Srithika and Bhattacharyya (2009), any type of learning would involve: (1) creation of new knowledge; and (2) getting rid of obsolete knowledge. How will the teacher facilitate presenting new information if the students have previously acquired a particular idea which happens to be contradicting?

The aforementioned only talked about knowledge on a cognitive level. Situations get more complicated if the teaching-learning process involves attitudes and behaviors, because there are so-called "human bins" as coined by Nonaka\& Takeuchi (1995), as cited by Srithika (2009). Such "human bins" are implicit knowledge, skills, attitudes, and cultures stored in the minds of the people, thus making it more difficult to discard. Though these elements are subject to change, the teacher is competing with other internal and external influences-the family, the peer groups, mass media, the church, the community in general, and even the genetic make up of the child. As Semetsky\&Lovat (2011) argue, "in the process we will be confronting ourselves, including our own comfort zones of knowing; those familial, cultural, religious and dispositional preferences that, having so far provided a feeling of inner security, have become part of our habitual identity."

Speaking of attitudes and behaviors, in the setting of EdukasyonsaPagpapakatao(EsP), the localized and contextualized term for Values
Education in the Philippines, these various institutions (family, peer groups, school, community, media, church) were all given emphasis in the curriculum. As a matter of fact, the major themes that categorize the competencies are actually based on these institutions. The K-12 Basic Education Program (2013) for the subject area EsP places itself in a position that is centered on the learners' responsibility in their decisions and actions, towards the common good. This is even more strengthened by the curriculum's advocacy of guiding the learners understand the personal meaning and purpose of life, and the role they play in the community. In fact, the five (5) macro skills described as the expected competencies of the learners are all reflective of a harmonious relationship between intrapersonal and interpersonal orientation of valuesunderstanding, reflection, consultation, decision-making, and action. Individuals are products of $21^{\text {st }}$ century education are geared with generic skills of critical and higher order thinking skills, digital literacy, etc. (Serbo \& Ancho, 2019).

Since this study is moving towards a creation of a new teaching approach in EsP, the researchers also explored the existing approaches of EsP as stated in the curriculum guide. According to the document, the prescribed approaches to teaching EsP include the following: (1) the ethical decision-making approach, which involves the formation of a decision which prefers what is good, and develops the character of the individual; and (2) the social-emotional learning approach, one that emphasizes knowledge and understanding of the self, concern for others, communication skills, and effective management of difficult situations. Thus, examination of one's thoughts and feelings play an important role in the process of unlearning. Education is seen as a change 
driver towards 'quality and public life' (Sulimah et al., 2019). Having these circumstances in mind, it is indeed a challenge for teachers to "facilitate" change in the students. Panturi and Anggraeni (2019) have emphasized that educational experiences are essential to 'globally competent teachers'. As far as the subject area EsP is concerned, And so the researchers have placed interest upon how this takes place, and how the educational community can make a difference about it. It is hoped that the outcome of the study can serve as an alternative, yet equally effective approach in facilitating lessons in the subject area.

\section{Role of Unlearning in the Curriculum}

The journey to the study's intended outcome was indeed a challenging task, because the researchers are dealing with a facet of human character that is already established, if not permanent. As argued by Wilson (1988), "we are prisoners of our previous learning. If later knowledge is to be securely based, then the foundation must be accurate; faulty items do not simply decay they still have their place in the schema and still exert an influence." A significant hurdle to learning is not the absence of knowledge, but rather the existence of prior knowledge (Lyndon, 1989). One could presume that it is easier to fill an empty glass with water, than to remove the existing water, and replace it with a new one.

There are differing views about the position of unlearning in the learning process. For some, it falls under learning or within learning (Huber 1991, as cited by Tsang, 2008). Others view it not as part of learning, but only as a preparatory stage to learning (Zahra \& Tsang, 2011). It is also viewed that unlearning and learning are a pair of symmetrical processes (Savage \& Ziemke,
2000). Furthermore, the process itself is as unsettled as its position. To unlearn is not synonymous to "undo". The human mind does not resemble a computer who can simply rewind its previous action, and delete the current one. Unlearning involves abandonment of established ideas (Hislop et al., 2014), release or discard of obsolete or unhelpful beliefs (McKeown, 2012), setting aside of established understandings (Howells \& Scholderer, 2016), and ultimately, embracing of new knowledge, beliefs, and practices (McKeown, 2012). Amidst all of these definitions, it is synthesized that scholars unanimously agree that unlearning involves an element of change. By combining these definitions, it becomes evident that unlearning (a) is concerned with removing/discarding knowledge, (b) can have some subjective value attached to it, such as 'obsolete', 'irrelevant', 'unuseful,' etc., and (c) can either be an end by itself or act as a means to a final end, viz., learning or change (Sirthika, 2009).

Nature of Adolescents as Learners and Their Potential to be Unlearners

Though the complexity and rigor of the process of change may pose a challenge for unlearning to successfully take place, the researchers see this as an opportunity to be more steadfast in reframing some of the "solid concepts" which may seem obsolete or unhelpful. As a matter of fact, the researchers trust in the potential of adolescents as the most appropriate age of learners to participate in the study. Speaking of change and instability, adolescence has been marked as a "time of change or turning point" where teenagers reinvent and redefine their identities (Erikson, as cited by Fleming, 2004), a time when individuals gain new and more mature understandings from active construction, rather than mere reception of knowledge 
(Piaget, as cited by Wood et al., 2001), a period when moral development becomes a product of students' own thinking (Kohlberg, 1971). However, amidst all of these studies speaking of change, the researchers are also aware of the fact that adolescents also struggle with their fidelity to one's sense of self and faith in one's ideology (Erikson, as cited by Fleming, 2004).

The review of related literature has opened our eyes to the understanding that adolescents are naturally unstable and exploratory, and so there is a need for the EsP curriculum in the Philippines to be more dynamic and open to change. Unlike other subject areas where learning objectives are determined and exact, EsP's competencies are more challenging because values are acquired not from academics alone, but from other social institutions where the learners interact. Thus, the curriculum needs to acknowledge the diverse and changing values of students, particularly the ones in adolescent stage.

This is where the concept of unlearning will come in-on how students will reframe the values they have acquired from the other institutions of the society, in order to embrace the values being promoted to them as learners of the EsP curriculum. However, different scholars also have diverse views on unlearning. In order to address this unsettled issue, this study is geared towards providing enlightenment on how the process of unlearning takes place, and how it can be contextualized in the educational setting to serve as a bridge between one's existing habits/attitudes and the values being taught in EsP, which is somewhat a reflection of bridging the gap between the learner's hidden curriculum and the subject's intended curriculum.

\section{Statement of the Purpose}

The study intended to formulate an approach in teaching Edukasyonsa Pagpapakatao that focuses on how students, particularly adolescents, can unlearn their negative habits. This approach will be grounded from the experiences and perspectives of teachers and learners.

\section{Research Questions}

1. How do Grade 7 students unlearn negative habits?

2. How do EsP teachers facilitate the students' unlearning of negative habits?

3. Based on the results of the study, what unlearning approach could be developed in teaching EsP?

\section{METHODE}

\section{Qualitative Desin and Methodology}

The researchers extrapolate that the study is qualitative in nature, because the intent is to explore an under-researched aspect of teaching and learning, that is, unlearning. Furthermore, it seeks to describe and explain the role of unlearning in the learning process from the lens of teachers and students in the grassroots level. Since existing local literature is weak, there was heavier reliance on data coming from the participants, and so qualitative methods were preferred.

\section{Thematic Analysis}

Thematic analysis is a type of analyzing qualitative data sets (self-reports, interview transcripts, narratives, focus group discussions, etc.) to look for "themes" or patterns that describe the phenomenon being explored in a given research study. It goes beyond employing a word count or interpreting the data superficially, but it also examines the deeper, often implicit meanings behind participants' responses, and builds a relationship among these discovered meanings. 
Due to this characteristic of thematic analysis, the researchers are also the instrument, in the sense that the study relies on his/her capability of describing, understanding, and interpreting the participants' responses, to be able to yield meaningful information. Thus, in this type of analysis, the subjective and personal biases, judgments and values of the researchers are taken into consideration, and respected by the academic community. However, to be accepted as trustworthy, "qualitative researchers must demonstrate that data analysis has been conducted in a precise, consistent, and exhaustive manner through recording, systematizing, and disclosing the methods of analysis with enough detail to enable the reader to determine whether the process is credible." (Nowell, Norris, White, \&Moules, 2017, p. 1)

\section{Research Locale}

The study was conducted in a private Catholic educational institution situated in the city of Imus, province of Cavite, Philippines. It was established in 1998, as an addition to its main campus in Las Pinas City. It offers integrated basic education programs starting from Kindergarten to Grade 12, which emphasizes multiple intelligences, entrepreneurship skills, Filipino heritage, and Catholic faith. It has a population of approximately 1,200 students and 100 teaching faculty members.

\section{Selection Criteria and Participants}

From a developmental perspective, the researchers intentionally preferred Grade 7 students (normally ranging from 12-14 years old) to target the onset of adolescence which is theoretically perceived to be a period where individuals struggle to form their identities, while being influenced by external factors which shape their habits. This is also in congruence with the
EsP Curriculum for Grade 7 in which the major theme is the individual or the self (sarili) as indicated in the curriculum guide. Purposive sampling is deemed to be the suitable manner of selecting participants since the study requires a certain criteria for people to participate. In the context of the research, these criteria are as follows: (1) a bona fide Grade 7 student, 12 to 14 years of age; and (2) must be taking up the subject EsP.

On the other hand, teachers participated in the study were subject to the following qualifications: (1) a Values Education teacher implementing the EsP Curriculum; (2) must be teaching, or had an experience teaching EsP Grade 7 or at least under the high school department. A number of 33 respondents (students and teachers combined) were considered to be enough for the study, anticipating that this amount has provided enough theoretical saturation and richness of data. This number is also recommended by Morse (1994) and Creswell (2013) as cited by Guetterman (2015). Moreover, the average class size in the research site is 30 , which is why this number may at least be reflective of the individual differences in a particular class.

\section{Profile of Respondents}

The researchers looked into the responses of the people who are in the grassroots level of the educational system: the teachers and learners. It is assumed that they have an in-depth perspective of looking at the curriculum since they are its primary implementers and beneficiaries. In this study, respondents were classified in two (2) sets: Set A for Learners, and Set B for Teachers. Following the selection criteria, the following are the respective sample sizes for each set: 
Table 1. Number of respondents.

\begin{tabular}{ll}
\hline Set of Respondents & $\begin{array}{l}\text { Number of } \\
\text { Respondents }\end{array}$ \\
\hline A (Students) & 25 \\
\hline B (Teachers) & 8 \\
\hline Total & 33 \\
\hline
\end{tabular}

Table 2 below shows how the learners vary according to gender and age. It can be seen that $76 \%$ (19 out of 25$)$ are male, and $24 \%$ (6 out of 25 ) are female. As far as their responses are concerned, there were no reported gender-related differences in terms of their previously learned habits. As a matter of fact, learners in this stage belong to heterosexual groups of friends which break gender stereotypes and typecasts.

In terms of age, $64 \%$ of the respondents are aged 12 , which is biologically, emotionally and socially the onset of adolescence. Due to this transition in life, most respondents reported an experience of adjustment to new things, increase in expectations and demands from other people, and transfer of one's inclination from family to friends.

Table 2. Profile of respondents (Set A).

\begin{tabular}{lc}
\hline \multicolumn{2}{c}{ Gender } \\
\hline Male & 19 \\
\hline Female & 6 \\
\hline \multicolumn{1}{c}{ Age } & 1 \\
\hline 11 years old & 16 \\
\hline 12 years old & 8 \\
\hline 13 years old
\end{tabular}

Unlike the previous set, Table 3 on the next page stipulates that the teachers who responded in the study have a fair distribution across genders and age groups. $50 \%$ (4 out of 8 ) are male, while the remaining $50 \%$ are female. As far as the data analysis of their responses are concerned, there are no reported gender-related differences on teachers' perspectives on learners' habits, as well as the process of unlearning. Similarly, their tenure as EsP teachers does not emerge as a significant theme in their responses.

Age is somewhat a contributory factor, since a number of respondents attributed their perspectives to issues such as how they have been raised by their parents during their generation, evolution of discipline approaches across time, and differences between the interests of their generation and the generation of their learners.

Table 3. Profile of respondents (Set B).

\begin{tabular}{ll}
\hline \multicolumn{1}{c}{ Gender } & 4 \\
\hline Male & 4 \\
\hline Female & 1 \\
\hline \multicolumn{1}{c}{ Age } & 0 \\
\hline 21-25 years old & 3 \\
\hline 26-30 years old & 3 \\
\hline $31-35$ years old & 1 \\
\hline $36-40$ years old & \\
\hline 41-45 years old & 3 \\
\hline \multicolumn{2}{c}{ No. of Years in Teaching } \\
\multicolumn{2}{c}{ EdukasyonsaPagpapakatao } \\
\hline 1-5 years & 4 \\
\hline 6-10 years & 1 \\
\hline $11-15$ years
\end{tabular}

\section{Data Collection Process}

The process of collecting data is divided into three stages: (1) pre-collection activities, (2) data collection proper, and (3) postcollection activities. As shown in the illustration, the preliminary data collection measures sought the consent of various internal and external stakeholders of the Elizabeth Seton School: administrators, parents/guardians, teachers, and students. The researchers also pursued the experts' validation of the research instrument, in order to assure that interview questions are congruent to the intent of the study, and are observant of ethical interview practices. Data collection proper was implemented for approximately three months, given that each school day is allotted for one respondent. 
The duration of each interview, however, is varying, depending on the researchers probing questions and the participant's volume of responses. Since the researchers conducted interviews that are semistructured, there are instances when the discourse of the interaction would somehow deviate from the interview guide, especially when some of the respondents emphasized a particular issue not intended by the researchers. Throughout the course of the interview, an audio recording device was used to enable to researchers to accurately transcribe the responses at a later point in the study. Finally, the researchers rigorously transcribed the interview records, paying accurate attention not only to how the participants verbalized their thoughts, but also to how the probing questions were tailored. This yielded the transcripts of all interviews, to be further analyzed using the techniques of thematic analysis.

\section{Data Analysis}

The data analysisinvolved thirty-three transcripts of interviews (students and teachers combined) transcribed through Microsoft Word and a mobile audio recording app. Zooming in the lenses further, each transcript was read and understood in detail, and the researchers highlighted meaningful text segments which are potential codes. Each code was assigned with a particular color, to enable the researchers distinguish among various codes. Codes were then grouped according to each interview question. By the time the codes were organized, the researchers grouped the similar codes in categories to form broader and more encompassing groups now called themes. These themes were then refined and synthesized, with respect to the given research questions.

\section{RESULT AND DISCUSSION}

The succeeding tables will enable the readers to take a closer look in the participants' reported perspectives and experiences about the research questions. It is organized into two columns: (1) the core themes or key results, and (2) the sub-themes classified under each core.

\section{How do Grade 7 students unlearn negative habits?}

Table 4. Responses and themes for research question 1 .

\begin{tabular}{|c|c|}
\hline Core Themes & Sub-Themes \\
\hline \multirow{4}{*}{$\begin{array}{l}\text { Unlearning } \\
\text { through a } \\
\text { developmental } \\
\text { process that links } \\
\text { the past, present, } \\
\text { and future }\end{array}$} & $\begin{array}{l}\text { Unlearning by building on } \\
\text { learnings from one's past }\end{array}$ \\
\hline & $\begin{array}{l}\text { Unlearning by examining } \\
\text { the effects of one's previous } \\
\text { habit }\end{array}$ \\
\hline & $\begin{array}{l}\text { Unlearning through passing } \\
\text { of time }\end{array}$ \\
\hline & $\begin{array}{l}\text { Unlearning through the } \\
\text { progression of small steps }\end{array}$ \\
\hline \multirow{3}{*}{$\begin{array}{l}\text { Unlearning by } \\
\text { propelling the } \\
\text { person beyond the } \\
\text { old habit to more } \\
\text { possibilities and } \\
\text { opportunities }\end{array}$} & $\begin{array}{l}\text { Unlearning by substituting a } \\
\text { replacement }\end{array}$ \\
\hline & $\begin{array}{l}\text { Unlearning by looking at } \\
\text { options or alternatives }\end{array}$ \\
\hline & $\begin{array}{l}\text { Unlearning by changing } \\
\text { one's perspective }\end{array}$ \\
\hline \multirow{4}{*}{$\begin{array}{l}\text { Unlearning by } \\
\text { operating on the } \\
\text { will power of the } \\
\text { person to unlearn }\end{array}$} & $\begin{array}{l}\text { Unlearning as a self-directed } \\
\text { process }\end{array}$ \\
\hline & $\begin{array}{l}\text { Unlearning as a process of } \\
\text { acting, more than a process } \\
\text { of thinking }\end{array}$ \\
\hline & $\begin{array}{l}\text { Unlearning by being } \\
\text { determined to stop }\end{array}$ \\
\hline & $\begin{array}{l}\text { Unlearning by regulating or } \\
\text { controlling oneself }\end{array}$ \\
\hline \multirow{3}{*}{$\begin{array}{l}\text { Unlearning by } \\
\text { involving the } \\
\text { participation of } \\
\text { the surrounding } \\
\text { people }\end{array}$} & $\begin{array}{l}\text { Unlearning by asking help } \\
\text { from others }\end{array}$ \\
\hline & $\begin{array}{l}\text { Unlearning through } \\
\text { distancing from the } \\
\text { influencers of one's previous } \\
\text { habit }\end{array}$ \\
\hline & $\begin{array}{l}\text { Unlearning through learning } \\
\text { from others especially } \\
\text { models }\end{array}$ \\
\hline
\end{tabular}


Table 4 meticulously defines the concept of unlearning, as grounded from the respondents. It offers various and diverse views about the study's central phenomenon of interest. Along the course of interviews, respondents suggested a number of plans and processes on how an individual can personally facilitate unlearning. Most respondents view unlearning as a difficult, challenging process, because it deals with aspects of one's character that are already established. They often associate unlearning with terms like forgetting, replacement, undoing, stoppage, etc. For them, it is something that starts with the self. It is more of a personal concern than an academic issue. However, even if unlearning is highly intrapersonal, teachers and students both believe that it builds on the collaborative support of all institutions (family, school, society, media) that shape one's habits and attitudes.

In addition, Table 4 also gives supplementary information about the identity of the respondents, both in terms of breadth and depth. It discusses and analyzes the learners' views about themselves, through their own lenses and those of their teachers. Specifically, the data looks into their perceived habits and attitudes - how they came into being, and how these affect their everyday lives. Generally, the Grade 7 students are highly interpersonal individuals who value the expectations, opinions, and values of others. However, despite being people-oriented, they also have a strong desire to manage their sense of self, but several internal and external factors get in the way. At this stage of life, their most prevalent issues are adjustment with new things and overuse of their freedom, especially in the use of technology.

\section{How do EsP teachers facilitate the students' unlearning of negative habits?}

Table 5. Responses and themes for research question 2.

\begin{tabular}{|c|c|}
\hline Core Themes & Sub-Themes \\
\hline \multirow{2}{*}{$\begin{array}{l}\text { Teaching by } \\
\text { empowering the } \\
\text { learners' autonomy } \\
\text { and decision to } \\
\text { unlearn }\end{array}$} & $\begin{array}{l}\text { Teaching by facilitating } \\
\text { unlearning in a personal } \\
\text { level, instead of academic } \\
\text { level }\end{array}$ \\
\hline & $\begin{array}{l}\text { Teaching not towards } \\
\text { changing to learners, but } \\
\text { towards guiding and } \\
\text { reinforcing them }\end{array}$ \\
\hline \multirow{4}{*}{$\begin{array}{l}\text { Teaching with more } \\
\text { emphasis on } \\
\text { personal } \\
\text { experiences than } \\
\text { subject matter }\end{array}$} & $\begin{array}{l}\text { Teaching by facilitating } \\
\text { unlearning in a personal } \\
\text { level, instead of academic } \\
\text { level }\end{array}$ \\
\hline & $\begin{array}{l}\text { Teaching through initiating } \\
\text { learning experiences that } \\
\text { are impactful and life- } \\
\text { changing }\end{array}$ \\
\hline & $\begin{array}{l}\text { Teaching through } \\
\text { facilitating personal } \\
\text { communication with the } \\
\text { learners }\end{array}$ \\
\hline & $\begin{array}{l}\text { Teaching with the } \\
\text { application of their own } \\
\text { experiences to gain } \\
\text { learners' trust }\end{array}$ \\
\hline \multirow{4}{*}{$\begin{array}{l}\text { Teaching through } \\
\text { helping learners } \\
\text { reconcile multiple } \\
\text { sources of } \\
\text { information }\end{array}$} & $\begin{array}{l}\text { Teaching by helping } \\
\text { learners establish ethics, or } \\
\text { understanding what is right } \\
\text { and wrong }\end{array}$ \\
\hline & $\begin{array}{l}\text { Teaching with God as part } \\
\text { of the unlearning equation }\end{array}$ \\
\hline & $\begin{array}{l}\text { Teaching by guiding } \\
\text { learners in synthesizing } \\
\text { pieces of learning from } \\
\text { different people }\end{array}$ \\
\hline & $\begin{array}{l}\text { Teaching by } \\
\text { acknowledging all points } \\
\text { of view through respect } \\
\text { and impartiality }\end{array}$ \\
\hline
\end{tabular}

Table 5 emphasizes the role of curriculum in the unlearning process. It analyzes how the respondents see teaching and learning as contributors to the process of unlearning. It also explores the relationship between the learners' habits/attitudes and values being taught by the 
teacher in the classroom, which may be reflective of a connection between intended and hidden curriculum.

Zooming the lenses further, this table looks into the academic aspect of unlearning, specifically in terms of lesson planning, designing, and implementation. It offers the respondents' ideas on what measures can be carried out by teachers in the classroom, to be able to facilitate unlearning.

Based on the results of the study, what unlearning approach can be developed in teaching EsP?

\section{Unlearning Approach in Teaching EdukasyonsaPagpapakatao: E.L.S.A.'s Approach to Unlearn}

Table 6. Design and Development of the Approach.

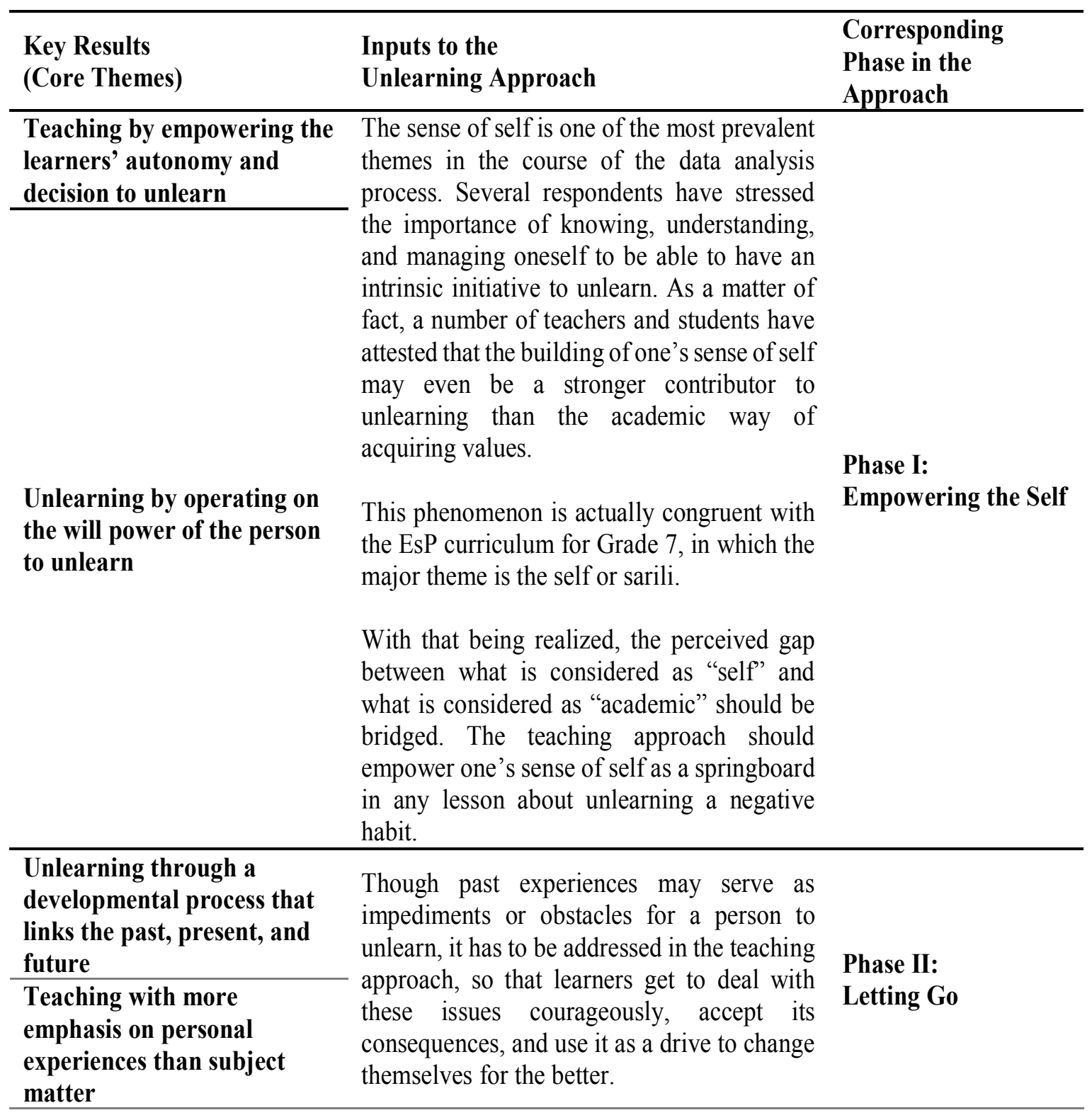




\begin{tabular}{ll}
$\begin{array}{l}\text { Unlearning by propelling the } \\
\text { person beyond the old habit } \\
\text { to more possibilities and } \\
\text { opportunities }\end{array}$ & $\begin{array}{l}\text { Letting go of one's negative habits must be } \\
\text { succeeded by a replacement of something } \\
\text { new. If some aspects of the self is unlearned } \\
\text { and left empty, there are high chances that it } \\
\text { will be acquired again. However, if this } \\
\text { empty space is occupied by something else, Starting a New Life }\end{array}$ \\
$\begin{array}{l}\text { Teaching through initiating } \\
\text { learning experiences that are } \\
\text { life-changing }\end{array}$ & $\begin{array}{l}\text { especially if impactful or life-changing, the } \\
\text { negative habit is less likely to be learned } \\
\text { again, even if encountered in the future. }\end{array}$ \\
\hline & $\begin{array}{l}\text { Considering habits from a behaviorist } \\
\text { perspective, one prevailing theme in the data } \\
\text { analysis is that unlearning is more of an }\end{array}$ \\
& $\begin{array}{l}\text { action, than of thinking. Similar to the } \\
\text { definition of learning as a change in behavior, }\end{array}$ \\
unlearning is also manifested not just through Phase IV: \\
cognitive indicators, but more importantly Action \\
through behavioral outcomes. Thus, the \\
of thing, more than a process \\
unlearning approach should be sealed with \\
authentic, real-life learning experiences \\
where students incorporate their new habits \\
into their daily lifestyles.
\end{tabular}

Table 6 points the relationship of the study's findings for research questions 1 and 2 to the unlearning approach that was formed as a response to research question 3 . The information above shows how the key results informed the fundamental phases of the unlearning approach. Since the data analysis adopted a number of techniques from Grounded Theory methodology, it is explicitly shown how the unlearning approach is built on the inputs of the study's findings. However, it is interesting to note that though the stages in the process of unlearning (empowering the self, letting go, starting a new life, and action), were grounded from the data, it coincidentally happens to be congruent with the existing macro skills of EsP curriculum in the Philippines, which includes understanding, reflection, decisionmaking, and action. Thus, it will be convenient for teachers to employ this approach in the classroom because it finds some alignment with their existing practice.

\section{Overview of the Approach}

The E.L.S.A.'s Approach to Unlearn is a teaching approach that aims to help students unlearn negative habits through the subject EsP. It goes through four important phases: (1) Empowering the Self, where students become more aware of aspects about oneself, be able to communicate these to others, and show independence and autonomy in directing their decisions and actions; (2) Letting Go, where learners are expected to examine the causes and consequences of one's negative habits, leading them to the realization of the need to unlearn; (3) Starting a New Life, which enables the students to set a goal and formulate a plan on how to initiate a new habit towards one's betterment; and (4) Action, wherein learners finally maintain the new habit on a regular basis in real-life settings. 


\section{CONCLUSIONS Conclusions}

Considering the findings of the study, the researchers interpreted the aforementioned data to enlighten the readers about new pieces of knowledge that can be learned from the study, be contributed to the growing body of literature, and be applied in the academe. The following conclusions are drawn:

1. Unlearning habit of Grade 7 students involves learning it deeply and wholly first, before letting it go. If a person unlearns a habit right away, he/she would miss the opportunity of learning from his/her mistake. Then, once the old habit has been examined, the learner can now divert his/her time and attention to potential new habits. Fundamental factors contributing to the facilitation of unlearning in the classroom include: (1) knowing the learners, (2) planning, (3) directing the self, (4) experiencing an impactful or life-changing event, and most importantly, (5) having the decision to unlearn.

2. The unlearning approach in teaching EsP does not aim to block or prevent potential habits from coming back, but rather enables the learner to effectively deal with these habits should it be encountered again in the future.Unlearning is an initiative of the teacher, but a decision of the learner.

3. The E.L.S.A.'s Approach to Unlearn is a teaching approach that aims to help students unlearn negative habits through the subject EsP. It goes through four important phases: (1) Empowering the Self; (2) Letting Go; (3) Starting a New Life; and (4) Action.

\section{Limitations of the Study}

Though the preceding sections yielded a rich amount of information with respect to the study's purpose, the researchers humbly acknowledge the research's potential areas for improvement.

1. The idea of unlearning is not an experimental process or behavioral modification. It only explored the concept and process of unlearning, but did not necessarily aim to make unlearning take place on the psyche of the students.

2. Actual observation of classroom dynamics has not become part of the data collection process. It may be helpful if this was done as a supplement to the interviews conducted.

3. A content analysis of the teachers' learning plans may enhance the content of data gathering. Nevertheless, the teachers' input about facilitating unlearning as a natural process and not pre-planned suggest that the procedure conducted is sufficient to gather the data required.

4. Though detachment from parents was reported to be a theme of adolescent life, the study may have overlooked the possible role of parents in the process of unlearning. They could have been a significant contributor to the study since their exposure to the habits of learners are broader and deeper than those of teachers and other members of the school community.

5. The researchers assume that the process of unlearning is more challenging for learners in the rural areas, since their thoughts, words, and actions are more traditional and stationary. Since the study is limited to one (1) school only, which happens to be located in a sub-urban area (Imus City, Cavite), it would have been more comprehensive if a comparative study among various schools, including the ones in remote communities, was conducted.

6. The unlearning teaching approach that emerged from the study, do not necessarily guarantee the success of learning on the end 
of the students. This research is qualitative in nature, and not a quantitative measure of any correlation between unlearning and learning success, or even teaching effectiveness.

\section{Recommendations}

Zooming out the lenses further, the researchers open more possibilities on how the study can be applied in the external world where it revolves. Though qualitative studies are less generalizable, this section has provided a wide array of programs and services where the study's results can be utilized, with respect to the different areas of education.

1. One advocacy that this study has promoted is the self-direction of learners. Thus, it is suggested that scholars in the academe start looking into how learners can be more empowered in being autonomous in taking control of their own learning.

2. The line that draws the boundaries of learners' personal life and academic life is an interesting subject to study about, since this paper discusses how learners manage the things they learn from the different facets of their life. The curriculum must reflect, if not simulate, what is happening in real-life settings.

3. The process of unlearning may be contextualized in other subject areas, especially the ones that are skill-based (i.e. English/Filipino - in terms of unlearning speech expressions, grammar errors, etc., Mathematics - in terms of unlearning common arithmetic errors, Health - in terms of unlearning unhealthy habits and practices, etc.)

4. Since the study treated the concept of unlearning only in the level of meaningmaking, a longitudinal study may be conducted by psychologists to test for actual, empirical unlearning of behaviors over time, through experimental set-ups.

5. Researchers in Filipino anthropology and sociology could also draw inspiration from the results of this study. Since Filipinos are known for preserving traditions, beliefs, and customs, scholars may explore the process on how our citizens can unlearn perspectives and practices that are already obsolete or irrelevant to the modern times.

6. Schools need to redirect its student transition programs not towards persuading the learners to re-enroll in high school, but focused on supporting them in handling stress from the new expectations and demands of high school studies and lifestyle. Guidance offices may be tapped in pursuing this endeavor.

7. EsP teachers, textbook writers, and curriculum developers must reconcile or harmonize varying measures of what is "right" and what is "wrong". Learners have varied sources of values, which may create confusion and disorder in their decisionmaking skills. However, this practice must be done constantly, considering that values are changing.

8. As far as the researchers' awareness is concerned, the education system in the Philippines has no comprehensive program that ensures the teachers' in-depth knowledge about who their learners are. Each student has a different story to tell, and this is something teachers must explore before they can successfully teach. Teachers' knowledge of their learners is a prime characteristic of the unlearning approach, so it will be beneficial if a study will explore in what ways and levels do teachers get to know their students. Schools may consider the possibility of a mid-year curriculum evaluation conference (among its teachers) 
so that identified habits may serve as inputs to adding or contextualizing some lessons in the course syllabus.

9. Learners must be more empowered in planning and designing the curriculum, since they are its primary beneficiaries. Furthermore, they possess the habits, and so they should be involved in planning how to manage them. Since it may not be practical to collect the suggestions of the learners individually, this endeavor can be worked out in partnership with the class officers of each section and members of the Student Council. 10.Since the study gave birth to a teaching approach in EsP, it is highly recommended that a follow-up study be implemented, to design specific strategies, methods, and techniques for teaching and learning that subscribe to the idea of the unlearning, so that the teaching approach would materialize. In such follow-up, the involvement of the parents may be added to the corpus of the research to tackle the possible role of parents in the unlearning process.

\section{REFERENCES}

Cuban \&Spiliopoulos (2010). The grounded theory method of analysis in home/work study. Retrieved from: http:// www.lancaster.ac.uk/fass/projects/ homew ork/Docs / S trand\%202Grounded\%20theory\%20Data\%20Analysis.pdf Department of Education - Philippines (2013). K-12 Curriculum Guide for EdukasyonsaPagpapakatao Grades 1-10

Fleming, J. S. (2004). Erikson's Psychosocial Developmental Stages. Retrieved from h t t p : / s w p pr.org/t ex tbook/ ch\%209\%20erikson.pdf

Freiberg, H.J. \& Foster, D. (1979). Who should facilitate values education. Journal of Teacher Education, 30(3), 37-40.
Guetterman, Timothy C. (2015). Descriptions of Sampling Practices Within Five Approaches to Qualitative Research in Education and the Health Sciences [48 paragraphs]. Forum Qualitative Sozialforschung/Forum: Qualitative Social Research, 16(2), Art. 25, Retrieved from: http://nbn-resolving.de/urn:nbn:de:0114fqs 1502256.

Hadley, Debbie. (2018). The Firefly Life Cycle. Dotdash Publishing - ThoughtCo. Retrieved from https:// www.thoughtco.com/life-cycle-fireflieslightning-bugs-1968137

Hislop, D., Bosley, S., Coombs, C. R., \& Holland, J. (2014). The process of individual unlearning: a neglected topic in an underresearched field. Journal of Management Learning, 45(5), 540-560.

Howells, J. \&Scholderer, J. (2016). Forget unlearning? How an empirically unwarranted concept from psychologywas imported to flourish in management and organization studies. Journal of Management Learning, 47(4), 443-463.

Jensen E. (2012). Notes on data analysis following grounded theory approach. Retrieved from http:// www2.warwick.ac.uk/fac/cross_fac/ esrcdtc/coretrainingmodules/ird/ p s r m o d u l e o u t 1 i n e / notes_on_data_analysis_following grounded_theory_approach.pdf

Kohlberg, L. (1971). Stages of moral development.Retrieved from http:// in fo.psu.edu.s a/p su/math s/ Stages $\% 20$ of $\% 20$ Moral\%20Development \%20According\%20to\%20Kohlberg.pdf

Mack, N., Woodsong, C., MacQueen, K.M., Guest, G., Namey, E. (2005). Qualitative research methods: a data collector's field guide. North Carolina, USA: Family 
Health International. Retrieved from:https:/ /www.fhi360.org/sites/default/files/media/ documents/Qualitative\%20Research $\% 20 \mathrm{Methods} \% 20-\% 20 \mathrm{~A} \% 20$ Data\%20Collector's\%20Field\%20Guide.pdf McKeown, I. (2012). Teaching old dogs new tricks: why unlearning matters in SMEs. Journal of Entrepreneurship and Innovation, 13 (1), 25-34.

Panturi, H.\&Anggraeni, A. (2019).Enriching Teachers' Pedagogical Stategy Using the Role of Global Competence Learning Model. Jurnal Pendidikan Progresif, 9 (1), 2939.

Savage, T. \&Ziemke, T. (2000).Learning and unlearning mechanisms in animals. Journal of Adaptive Behavior, 8(2), 97-128.

Serbo, S. \&Ancho, I. Authentic Learning in Teaching Economics.Journal of Research, Policy, \& Practice of Teachers \& Teacher Education, 9 (1), 1 - 11.

Semetsky, I. \&Lovat, T. (2011).Bringing Deleuze's philosophy into discourse on values education and quality teaching: an Australian model.Policy Futures in Education, 9,(4), 485-493.

Srithika, T. M. \& Bhattacharyya, S. (2009). Facilitating organizational unlearning using appreciative inquiry as an intervention.Vikalpa: Journal for Decision Makers, 34(4), 67-77.

Sulimah, Sulistya, D., Fitri, S. (2019). Improving Students' Learning Achievement Through Think, Talk and Write (TTW) Learning Model. JurnalPendidikanProgresif, 8 (1), 10-17.

Tsang, E. W. K. \& Zahra, S. A. (2008). Organizational unlearning.Journal of Human Relations, 61 (10), 1435-1462.

Tsang, E.W.K. (2008). Transferring knowledge to acquisition joint ventures: an organizational unlearning perspective.
Journal of Management Learning, 39(1), 5-20.

Wilson, D.G. (1988). The invaluable art of unlearning. Journal of the Royal Society of Medicine, 81, 3-6.

Wood, K. C., Smith, H. \&Grossniklaus, D. (2001). Piaget's stages of cognitive development.Retrieved from http:// epltt.coe.uga.edu/index.php? title $=$ Piaget $\% 27 \mathrm{~s} \_$Stages

Zahra, S. A., Abdelgawad, S. G., \& Tsang, E. W. K. (2011). Emerging multinationals venturing into developed economies: implications for learning, unlearning, and entrepreneurial capability. Journal of Management Inquiry, 20(3), 323-330. 